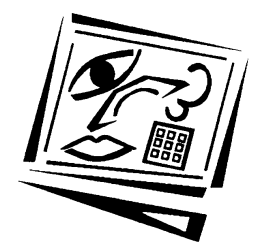

\title{
Building the capacity of Indonesian education universities for ICT in pre-service teacher education: A case study of a strategic planning exercise
}

\author{
Cher Ping Lim \\ The Hong Kong Institute of Education \\ Paulina Pannen \\ Sampoerna School of Education, Indonesia
}

\begin{abstract}
This paper documents how four Indonesian teacher education institutions (TEIs) engaged in strategic planning to build their capacity in developing pre-service teachers' ICT in education competencies. These TEIs adopted a holistic approach towards strategic planning by drawing upon the six dimensions of the Capacity Building Toolkit for TEIs in the Asia Pacific. The core dimension is the pre-service teacher education program (curriculum, assessment and practicum) that is driven by the vision and philosophy of a TEI. The program is supported by four other dimensions of professional learning, ICT plan, communication and partnerships, and research and evaluation. Three of the four TEIs focused their strategic planning on the development of pre-service teacher education programs, while one focused on research and evaluation. In the process, the TEIs identified support from the management as pivotal in the implementation of the plan. However, they also encountered challenges in senior staff's reluctance to change, lack of funding, and shortages of qualified staff.
\end{abstract}

\section{Introduction}

Pre-service teacher education programs in education institutions (TEIs) play a crucial role in preparing quality teachers who are open to information and communication technologies (ICT), and are able to understand and accept the need for change (Bereiter \& Scardamalia, 2006; Cheng, 2009; Northcote \& Lim, 2009). In a context of increasing ICT literacy and rapidly growing availability of ICT infrastructure in Indonesia, the integration of ICT in the curriculum of teacher education programs in Indonesian TEIs is inevitable. However, integration of ICT does not merely mean an addition of tools, it changes everything about teaching and learning, and requires comprehensive and integrative planning of the ICT facade in teacher education (Wright, Dhanarajan \& Reju, 2009).

Based on the year-long project Leading ICT in education practices: A capacity building toolkit for teacher education institutions in the Asia Pacific in four Southeast Asian countries (Indonesia, Thailand, the Philippines, and Vietnam) from February 2010 to February 2011, this paper documents how four Indonesian TEIs engaged in a strategic planning exercise to build their capacity in developing pre-service teachers' ICT in education competencies. 


\section{The Toolkit and the project}

A capacity-building toolkit for teacher education institutions in the Asia-Pacific (referred to as the Toolkit in this paper) (Lim, Chai \& Churchill, 2010) provides a set of tools for TEIs to conduct needs and situation analyses of the state of their ICT use in teaching, learning and administration. By doing so, the TEIs are better positioned to develop a strategic plan to build their capacity in developing the ICT in education competencies of pre-service teachers. The Toolkit proposes a framework of strategic planning processes that encompasses six strategic dimensions which TEIs need to focus on:

1. Vision and philosophy;

2. Program - curriculum, assessment, and practicum;

3. Professional learning of deans, teacher educators and support staff;

4. ICT plan, infrastructure, resources and support;

5. Internal and external communication and partnerships;

6. Research and evaluation.

The year-long project aimed to lead TEIs to implement their strategies in three main phases:

1. A small-scale implementation of the toolkit involving three to five TEIs per country;

2. Scaling up of the implementation with TEIs from the first phase serving as peer coaches for more TEIs; and

3. Building and sustaining this community of TEIs.

This paper documents the results of phase (1) and its follow-up in four universities in Indonesia.

\section{The collective case study of four Indonesian TEls}

This section presents a case study of each of the four Indonesian TEIs, namely Yogyakarta State University (UNY), State University of Malang (UM), Indonesia University of Education (UPI), and Sampoerna School of Education (SSE). Findings discussed in this paper are based on document analysis of project proposals, supporting documents, self-reporting, and observations by the first two authors as participants in the project activities.

Of the four university teams, UNY, UM, and UPI focused on the use of ICT in Dimension 2 - Curriculum, assessment and practicum, which is the most crucial component in ICT integration involving a comprehensive set of indicators across teaching and learning practices. SSE chose to work on Dimension 6 - Research and evaluation, with the intention to develop its new Research and Development Division. The following presents details of the strategic planning efforts by the four TEIs.

\section{Yogyakarta State University (UNY)}

The UNY team focused on reforming practices of two programs in the Electronics Department - the Electronics Education (E.Edu) and the Information Technology Education (IT.Edu). They are both undergraduate level, pre-service teacher education programs training prospective vocational high school teachers. 
Analysis of the programs revealed that ICT has been used by some lecturers in the core courses of E. Edu and IT.Edu, but was not used for assessment nor practicum, and there was minimal linkage between courses based on competency analysis and pedagogical consideration. Thus they considered the programs undeveloped in Dimension 2. They set the goals of the project as to improve the quality of the curriculum and its implementation by integrating ICT into teaching and learning activities, expecting to achieve the following outcomes:

- Analyse the curriculum and develop five courses that accommodate the use of ICT in the teaching and learning process, including use of the learning management system (LMS) through the university's e-learning portal;

- Develop ICT-mediated teaching and learning activities for the courses; and

- Upgrade lecturers' ICT competencies.

Measurement of the outcomes is conducted by referring to the following performance indicators:

- $80 \%$ of the content of the curriculum involves use of ICT;

- All the content of the five courses is uploaded to the LMS; and

- All the teaching and learning activities of the courses are conducted as the planned scenarios.

The project was planned to run during the 2010-2011 academic year in nine steps:

1. Present the plan during the regional workshop organised by Microsoft;

2. Establish partnerships with Microsoft;

3. Analyse and revise curriculum;

4. Evaluate the existing LMS of the university;

5. Develop the courses:

6. Develop teachers' and students' manuals of the courses;

7. Implement;

8. Evaluate;

9. Report on the process.

\section{State University of Malang (UM)}

The UM team also focused on Dimension 2 of the Informatics Education Study Program, in the Faculty of Engineering. Graduates of the program are to become vocational high school teachers.

The situation analysis showed that use of ICT was quite common in teaching and assessment activities in the Department; and they were linked with students' practicum. UM also has a blueprint for ICT development which defines the need to apply ICT to both academic and administrative activities, but it does not include any requirement to use ICT for teaching activities. Thus the team set the goals of the project as to develop a prototype of curriculum through reforming four courses that integrate ICT in their teaching and learning activities. The performance indicators for the expected outcomes include:

- Requirements regarding the use of ICT in the lesson plans of the four courses;

- Lesson materials and a content management system (CMS) developed by using ICT; 
- Requirements regarding use of ICT in teachers' and students' manuals;

- Use of the CMS in teaching and learning activities.

The project was planned to be conducted in a one-year period in six steps:

1. Analyse and revise the existing curriculum and the lesson plans;

2. Develop a CMS based on the current academic management system;

3. Develop course content including teaching materials, virtual practicum, and assessment using software such as Marvin for the creation of simulations and animations;

4. Prepare teachers and students to use the CMS;

5. Implement;

6. Evaluate the process.

\section{Indonesia University of Education (UPI)}

UPI is one of the oldest universities in Indonesia with eight faculties. The UPI team also chose to work on Dimension 2, in the Faculty of Mathematics and Science Education which prepares Mathematics and Science teachers at primary and secondary level.

Analysis of current situation revealed that the ICT infrastructure was well built in the Faculty, where teachers and students enjoyed good access to the Internet and intranet; and every classroom was equipped with a computer and a projector. However, they saw challenges in the Faculty's efforts to increase students' ICT literacy and lecturers' use of ICT in teaching activities. Thus they set the goals of the project as to develop students' ICT literacy and increase lecturers' use of ICT in teaching, in the Faculty's compulsory Foundation Courses (MKKF). The MKKF includes four courses - Basic Mathematics, General Physics, General Biology, and General Chemistry which are offered across departments in the Faculty.

Through the project they expected to achieve the following outcomes:

- The faculty establishes a good foundation for developing ICT integration in its curriculum;

- Lecturers use more ICT in teaching and learning;

- Student teachers start using ICT for learning; and

- Student teachers' ICT literacy is improved.

The outcomes were evaluated against the following performance indicators:

- Lesson plans of the courses include requirements on use of ICT;

- The courses are prototyped in using ICT to support the running;

- Teachers' and students' manuals include requirements on use of ICT; and

- Pre- and post-test on lecturers and students indicate improvement of their ICT competencies.

The project was planned to be executed in the 2010-2011 academic year in five steps:

1. Analyse and revise the courses;

2. Develop a content management system;

3. Develop content; 
4. Develop teachers' and students' manuals; and

5. Implement and evaluate the project.

\section{Sampoerna School of Education (SSE)}

SSE is a relatively newly established teacher education institute, providing four-year undergraduate level programs for pre-service teachers to teach mathematics and English in secondary schools in Indonesia. Recognising the importance of developing ICT in education competencies of the new generation of teachers, SSE started to try integrating ICT in its academic process from the very first year of its establishment. Joining the project in its second year of establishment, the SSE team chose to work on Dimension 6 - Research and evaluation, with an intention to contribute to the development of the school's new Research and Development (R\&D) Division.

Results of situation analyses indicated that SSE was on a fundamental level of development in areas concerning research and development, whereas the areas pertaining to evaluation of the impact of $R \& D$ were undeveloped. The team outlined five areas of priority with target indicators in its 2010-2012 strategic plan, as presented in Table 1.

Table 1: Areas of priority and target indicators

\begin{tabular}{|c|l|l|}
\hline \multicolumn{2}{|c|}{ Area of priority } & \multicolumn{1}{c|}{ Target indicators } \\
\hline 1. & $\begin{array}{l}\text { ICT-related research capacity } \\
\text { building }\end{array}$ & $\begin{array}{l}\text { Academic staff have a good understanding } \\
\text { regarding use of ICT in teaching and learning and } \\
\text { the issues on ICT in education } \\
\text { Academic staff's research competencies are } \\
\text { improved }\end{array}$ \\
\hline 2. & $\begin{array}{l}\text { Providing support for ICT-related } \\
\text { research through research grant } \\
\text { schemes }\end{array}$ & $\begin{array}{l}\text { The number of ICT-related research topics in SSE is } \\
\text { increased } \\
\text { The types of research vary }\end{array}$ \\
\hline 3. & $\begin{array}{l}\text { Providing consultation services to } \\
\text { SES researchers }\end{array}$ & $\begin{array}{l}\text { More academic staff conduct ICT-related research } \\
\text { The quality of research is controlled }\end{array}$ \\
\hline 4. & $\begin{array}{l}\text { Research dissemination through } \\
\text { publication and seminars }\end{array}$ & $\begin{array}{l}\text { External parties have access to research } \\
\text { The concept of ICT-mediated teaching and learning }\end{array}$ \\
\hline 5. & $\begin{array}{l}\text { Developing networks with other } \\
\text { is widespread within the Indonesian education } \\
\text { system }\end{array}$ \\
funding and partnership & $\begin{array}{l}\text { External research funding is obtained } \\
\text { The Institute joins a wider academic community on } \\
\text { both national and international levels } \\
\text { Partnerships are built through conducting joint } \\
\text { research }\end{array}$ \\
\hline
\end{tabular}

Within the area of evaluation, the SSE team set priority on evaluating ICT-mediated teaching and learning. The process was designed to consist of five phases: (1) formulation of standards, (2) dissemination of standards, (3) regular monitoring, (4) analysis and evaluation, and (5) reporting and feedback. Started in 2010, the project was fully supported by the management and was expected to achieve the outcomes in 2012.

\section{Promising practices and challenges}

One of the key promising practices of this project is the teams' holistic approach to plan for the capacity building of their TEIs to develop pre-service teachers' ICT in 
education competencies. The project guided by the Toolkit allows universities to combine top-down and bottom-up approaches, evaluate their own situation, and develop a systematic perspective towards ICT in education planning. It serves as a strategic planning exercise for TEIs to carry out ICT in education planning that has an impact on the pre-service teacher education program.

The participating TEIs adopted an approach of working on one strategic dimension, with three focusing on Program and one on Research and evaluation. In their effort to transform practices within the programs, all of them chose to start from a few courses within one faculty or department by infusing more ICT in education components into the content, management, teaching and assessment of the courses; and by improving students and teachers' ICT literacy. In the case of SSE, they chose to develop its R\&D Division by providing more support for academic staff's research competencies and practices, and by evaluating ICT-mediated teaching and learning within the school. By focusing initially on one dimension for strategic planning, they were able to identify good practices and challenges that may provide support for larger-scale efforts in the future.

All teams received support from management in terms of infrastructure, hardware and software - though more limited in the case of UPI and UM than the other two teams. The UNY team was also supported with resources for developing lecturers' ICT competencies. However, they encountered challenges including senior staff's unwillingness to change, lack of ownership of the curriculum, lack of designated staff, and insufficient funding. They also found it difficult to convince management to fully accept the approach the Toolkit proposes: (1) Management tends to hold a managerial and administrative approach to the issue whereas the Toolkit provides a thorough guide to ICT in education planning from an academic perspective; (2) Management often perceives ICT as only one part of the overall university operation, whereas the Toolkit gives a holistic approach to ICT in education planning involving various aspects of university operation.

The Ministry of National Education of Indonesia has disseminated the Toolkit to about 36 TEIs across the country. The fact that ICT is often taken as a mere addition to the existing teaching and learning system poses a major obstacle. Most TEIs expect that the integration of ICT will not change the way they are running the academic process. However, as suggested in the Toolkit, the integration of ICT into the pre-service teacher education program is expected to bring about systemic changes within a TEI, and result in the creation a new culture and mindset towards teaching and learning. At this stage, the integration of ICT into teaching and learning in Indonesian TEIs has not been contextualised within an institutional systemic change and has led to only minimal development of ICT culture at the institute level.

\section{Conclusion}

This project was intended to engage TEIs to exercise strategic planning to build their capacity for ICT in pre-service teacher education. In its first phase, the goal of the project was met by selecting a few TEIs, and guiding them with the Toolkit through the process of strategic planning. By analysing the situation and needs of their own institute, the participants gained a systematic understanding of the six strategic dimensions involved in building an institute's capacity for developing pre-service teachers' ICT in education competencies. 
Three of the four TEIs chose to work on strategic Dimension 2, Program - Curriculum, assessment and practicum, which is central to preparing pre-service teachers with the necessary ICT and pedagogical competencies to integrate ICT in teaching, learning and administration in schools (Mims, Polly, Shepherd \& Inan, 2006). All of them focused on reforming a set of courses within a department or faculty by integrating ICT into the content, management, assessment and learning activities of the course, and by upgrading ICT competencies of teacher educators and student teachers. One university focused on Dimension 6 - Research and evaluation, in order to develop its new R\&D Division. The teams received support from management in terms of facilities and training; however, they were faced with the challenges of senior staff's reluctance to change, lack of funding, and shortage of qualified staff. This project has indeed provided opportunities for TEIs to engage in a systematic approach towards strategic planning for ICT in pre-service teacher education. It has also helped identify enablers and barriers to the capacity building of the TEIs. It suggests that strategic planning might initially focus on one dimension before considering a full and larger-scale implementation.

\section{References}

Bereiter, C. \& Scardamalia, M. (2006). Education for the knowledge age. In P. A. Alexander \& P. H. Winne (Eds.), Handbook of educational psychology (2nd ed.) (pp. 695-713). Mahwah, NJ: Lawrence Erlbaum.

Cheng, Y. C. (2009). Teacher management and educational reforms: Paradigm shifts. Prospects, 39(1), 69-89. http:/ / dx.doi.org/10.1007/s11125-009-9113-2

Lim, C. P., Chai, C. S. \& Churchill, D. (2010). Leading ICT in education practices: A capacity building toolkit for teacher education institutions in the Asia-Pacific. Microsoft: Singapore.

Mims, C., Polly, D., Shepherd, C. \& Inan, F. (2006). Examining PT3 projects designed to improve preservice education. Techtrends, 50(3), 16-24. http:/ / dx.doi.org/10.1007/s11528-006-7599-5

Northcote, M. \& Lim, C. P. (2009). The state of pre-service teacher education in the Asia-Pacific region. In C. P. Lim, K. Cock, G. Lock \& C. Brook (Eds.), Innovative practices in pre-service teacher education: An Asia-Pacific perspective (pp.23-28). Netherlands: Sense Publishers.

Wright, C. R., Dhanarajan, G. \& Reju, S. A. (2009). Recurring issues encountered by distance educators in developing and emerging nations. International Review of Research in Open and Distance Learning, 10(1). http:/ / www.irrodl.org/index.php/irrodl/article/view/608/1180 /

Authors: Professor Cher Ping Lim

Department of Curriculum \& Instruction, The Hong Kong Institute of Education 10 Lo Ping Road, Tai Po, New Territories, Hong Kong SAR

Email: clim@ied.edu.hk Web: Web: http:/ / ied.academia.edu/CherPingLim/About

Prof Dr Paulina Pannen, Sampoerna School of Education

Mulia Business Park, Building D, Jl. MT. Hariyono Kav. 58-60

Jakarta Selatan, Indonesia

Web: http: / / www.sampoernaeducation.ac.id/en/

Please cite as: Lim, C. P. \& Pannen, P. (2012). Building the capacity of Indonesian education universities for ICT in pre-service teacher education: A case study of a strategic planning exercise. In C. P. Lim \& C. S. Chai (Eds), Building the ICT capacity of the next generation of teachers in Asia. Australasian Journal of Educational Technology, 28(Special issue, 6), 1061-1067. http:/ / www.ascilite.org.au/ajet/ajet28/lim-cp.html 